\title{
Editorial
}

Mark Kingwell*

\section{Editorial Introduction to the Topical Issue “Does Public Art Have to Be Bad Art?”}

https://doi.org/10.1515/opphil-2019-0041

\section{Overview}

Both the title and the call for papers for this topical issue were phrased with deliberate provocation in mind. So many discussions of public art seem to involve contentious views, citizen outcry, and conflict between 'the general public' (who must experience and live with the art) and the creators or curators of that art (who can sometimes seem, or be, elitist, arrogant, and irresponsible). The provocation, therefore, was deliberate but not without reflection. We wanted the articles in this issue to extend and expand on familiar disputes between citizens and government agencies, or corporations, who might commission public art works. We also wanted, naturally, to query the notion of 'bad art' in the context of the public sphere, especially in the places where everyday experience leads us to expect encounters with public art: parks, plazas, shared courtyards, airports, subway systems.

It is worth noting the obvious links among these various sites, namely, that they are almost always urban and unavoidable. I may choose to drive to a non-gallery artwork such as Robert Smithson's Spiral Jetty (1970, Great Salt Lake, Utah), or Michael Elmgreen and Ingar Dragset's Prada Marfa (2005, Valentine, Texas), or Seven Magic Mountains (2016, Las Vegas, Nevada) by Ugo Rondinone, or Alfredo Barsuglia's Social Pool (2014, Mojave Desert, California). Here, remoteness is often part of the work. In these cited examples, desert or near wilderness is absolutely figured as part of the installation, as is the journey to overcome that remoteness. Similar logics can be observed in works in other topographies: isolated hilltops, remote forests, circuitous hikes. We might define these works as destination art, rather than public art, since they call to us from a distance and employ that distance as an essential element of their aesthetic effect, even as they refuse the confines of the gallery or museum space.

But in some cases, works of public art conjoin proximity with distance. Consider, for example, Diller Scofido + Renfro's Blur Building (Yverdon-les-Bain, Switzerland, 2002), which created an intersection of lake, bridge, building, and natural mist features to allow an experience of gorgeous uncanniness. Or Christo's monumental Floating Piers (Lake Iseo, Italy, 2018), which moved beyond earlier experiments with draped buildings in the centre of cities (the Arc de Triomphe in Paris, the Reichstag in Berlin) and the fabric gates in New York's Central Park, to create instead a destination experience of walking on water. One must also mention here the ill-fated large-scale project of Christo and Jeanne-Claude to cover California and Japan with giant umbrellas (1991), which resulted in two deaths. 'Bad public art' does not meet the case for such calamity, which among things was satirized by the television show The Simpsons, where the character Homer, doofus head of the family and briefly an aspiring public artist, muses on the inspiration provided by a dangerous installation: "Killer umbrellas? Excellent!"”.

Such excesses aside, public art in the usual sense functions at least in part via proximity, not distance. This aspect of publicness is clearly more available in urban settings than elsewhere. That is, such art must remain accessible to an ordinary public, not just a motivated (and perhaps affluent) one who can traverse

1 Season 10, Episode 19.

*Corresponding author: Mark Kingwell, University of Toronto, Toronto, Canada; E-mail: mark.kingwell@utoronto.ca

๖ Open Access. ๑ 2019 Mark Kingwell, published by De Gruyter. @(G) Attribution 4.0 Public License. 
distances both physical and economic. This aspect of 'traditional' public art removes an element of freedom that is woven into destination art as I have characterized it above, which involves a planned visit and therefore, assuming one is not dragged along unwillingly, the exercise of free aesthetic choice. For example: one may love or hate Anish Kapoor's Cloud Gate, known affectionately as 'The Bean' (2004, Chicago, Illinois), but there is no way to avoid its presence if one steps anywhere along the Chicago Millennium Park complex. Matters are likewise in one of the most notorious cases, Richard Serra's Tilted Arc (1981-1989, Manhattan, New York), which was controversial, among other reasons, because it made it harder for people to cross Manhattan's Federal Plaza. The work was unavoidable, physically as well as aesthetically. The main charge in the remarkable 1989 Federal lawsuit that led to the removal of Serra's work was, however, its perceived 'ugliness'.

For many, Tilted Arc is the baseline example of what goes wrong in discussions about public art. I happen to think it is a work of genius, as are many if not most of Serra's public pieces. There is one installed in the main airport of my home city of Toronto, Tilted Spheres (2002-04, installed 2007, Pearson International Terminal One, Toronto), and I make a point to visit it every time I am there, whether it is close to my departure gate or not; but I have, unsurprisingly, overhead many derogatory remarks about it, on the order of "Well, it's just slabs of metal, isn't it?" This absolutely echoes the kind of commentary you may hear in any modern art gallery the world over, usually in the clichéd claim that "my six-year-old could have done that." Such comments may be dismissed as philistinism, but when the gallery or site is a publicly funded one, the issues begin to press on institutions, curators, artists, and even fans of the given work. Often, this is a matter of finance: How can be paying for this dreck with our tax dollars? When, in 1989 the National Gallery of Canada acquired Barnett Newman's Voice of Fire (1967) for the then extravagant-seeming price of \$1.8-million, there was a national crisis. Its current value may be closer to $\$ 40$-million, but that does not convey experiences such as my vivid disappointment that, when I last visited Ottawa and the Gallery, it was being treated and therefore not visible. One could multiply the examples of this kind: works by Tracy Emin or the Chapman Brothers in England, say, or by Anselm Kiefer in Germany.

These narratives of 'controversy' or 'badness', which are really the same narrative over and over, are part of the stock-in-trade of the gallery world. There are also some enticing limit-cases concerning monumentality and its deployment as both aesthetic and moral (war memorials, statues, certain buildings). Is Norman Foster's 30 St. Mary Axe, known wryly as ‘The Gherkin' (2003), a work of public art? If so, is it a good or bad work of art? What about central London's other much discussed 'out of place' building, Renzo Piano's neo-Futurist Shard (2012)? Is that public art, good or bad? Meanwhile, is the Statue of Liberty a work of public art in a different sense? What about the Brandenburg Gates, the Empire State Building, the CN Tower in Toronto, the Oriental Pearl Tower in Shanghai, Notre Dame Cathedral, the Fontana di Trevi in Rome, Gaudi's La Sagrada Familia in Barcelona, or the Charles Bridge in Prague? Once more, one could multiply the examples - though I confess that most of those just listed are praised almost universally by citizens and visitors alike, and in that sense are neither bad nor controversial except to certain kinds of retrograde critics, such as Britain's Prince Charles.

As fascinating and important as such debates may be to the notion of publicness in a large sense, we do not pursue them directly here. Rather, the focus of the articles in this issue is on works of created explicitly for display in public spaces. This we regard as the minimalist definition of public art: accessible and sitespecific. But, as readers will quickly discern, there is a host of instabilities and controversies lurking in even the minimalist definition. What is public space? What counts as display? Are there multiple publics, not just a single mass of citizens in a given conurbation? If citizens think public art is bad, does that matter? Also, crucially, who gets to decide which art is going to be displayed in public? Since any one of these conceptual vectors can be made blurry by both controversy and sustained investigation, the overall effect of 'the question of public art' is murky but endlessly instructive - as indeed one might say that all genuine philosophical puzzles must be.

The standard definition of public space is that it is a public good. This holds with Henri Lefebvre's celebrated view concerning a citizen's 'right to the city'. More specifically, in economic terms, a public good should be non-rival (there is no competition for its enjoyment, no zero-sum game) and non-excludable 
(there are no gates to its enjoyment or use). We are forced to wonder, in addition to all aesthetic concerns, whether public art is a public good. And if so, what kinds of exclusion are in play? This in turn raises another issue captured by economic theory: is public art a positive or negative externality? An externality is any aspect of life not captured by contract. Cities offer many examples. Negative externalities are things like pollution, noise, and traffic. Positive externalities might include opportunities for cultural and erotic stimulation, community connection, and beauty. The question of bad public art goes to the heart of all this. In a sense, we are asking: is public more like pollution or more like the sight of a beautiful sunset over the skyline. Both are free, but that is not indicative of their value in our eyes.

\section{Articles}

The first line of Mary Beth Willard's abstract for "When Public Art Goes Bad: Two Competing Features of Public Art" sets the basic theoretical terms of the entire issue. "Not all public art is bad art," she writes, "but when public art is bad, it tends to be bad in an identifiable way." She concludes the abstract with an equally resonant claim: "[W]hile not all public art is bad, the features peculiar to public work encourage a latent tendency toward badness." This aligns with my own view as editor of this volume - hence the title and call, already discussed - but of course it is controversial as a basic position. The value of Willard's contribution lies in the careful assessment of categories of judgment and publicness. Taking a lead from Kendall Walton's well-known "Categories of Art” essay, she considers examples of 'good' and 'bad' public art, based on a stipulative definition of such works as "accessible to the public" and "minimally sitespecific." Installations by Richard Serra, Anish Kapoor, and Christo and Jeanne-Claude are considered. Jochen Gerz and Esther Shavez-Gerz's Monument Against Fascism (Hamburg-Harburg, 1986-1993) and Maya Lin's Vietnam Veterans' Memorial Wall (Washington, DC, 1982) are likewise referenced as examples of good public art, even works of genius.

These examples provide a contrastive argument with bad public art, but they also complicate the category of public art in ways already noted. The last two works are historical monuments in the form of public artwork, which must be distinguished categorically from aesthetic works with no historical or monumental ambitions, such as those by Christo, Serra, or Kapoor. Both monuments likewise proved controversial. I would add that the compromises surrounding Lin's Wall have been extensive, such that the addition of Frederick Hart's Three Soldiers statue (1984) has obscured or limited the stark non-figurative and declivity-driven impact of Lin's original work. Thus Willard argues that site-specificity and accessibility, which looked to be joined in the basic definition of public art, are in fact competing features: an accessible work may not be able to engage its site in any deep way, while a work actually transforming its site through emplacement may prove inaccessible.

In "Object-hood's Indecencies: Tilted Arc and the Lessons Learnt in Breakdown," Emily Dickson takes her theoretical orientation from philosopher Graham Harman's work on Martin Heidegger, and especially the school of thought now known as Object-Oriented Ontology (OOO). The central insight of this approach is rooted in Heidegger's memorable discussion in Being and Time (1927) concerning the nature of tools, and the distinction between presence-at-hand (Vorhandenheit) and readiness-to-hand (Zuhandenheit). To put matters very crudely, one might characterize a certain kind of metaphysical project as the quest for the present-at-hand: the thing itself, Being isolated from experience, the One distilled from the Many, and so on. Heidegger's brilliant insight here is that, once the distinction is exposed, readiness-to-hand is a more reliable pathway to fundamental ontology. This may seem counter-intuitive: if ready-to-hand is the kind of status that accrues to tools and instruments, for example, how can we avoid falling into a sort of utilitarian vortex, where we can only see the hammer (his famous example) as something to be used. The error here is to occlude from ourselves the fact that the very ease with which we grasp and employ the hammer reveals a complex of ontological meaning concerning Being. The hammer makes no sense absent its relation to Dasein's projects and ontological situatedness. A related example drives the point home: when I misstep on a staircase, or when a step is broken or missing, I come face to face with the ontological presuppositions of my being-here. Smooth functioning contains the germ of ontological insight, but it needs to be teased out via failure. 
Object-Oriented Ontology extends the argument by shifting the focus from Dasein or any individual consciousness to the objects themselves. On this view, the hammer is not just a revelatory tool that I might use, but in a sense a site of its own ontological meaning. This has, of course, proven a controversial position; nevertheless, in this article Dickson ably deploys the work to discuss Serra's Tilted Arc, and in doing so adds a new dimension to this much-discussed example of public art. Serra himself, protesting the dismantling of the work, had said "To remove the work is to destroy it." This naturally makes sense given premises of site-specificity and public accessibility - which, as we have seen, would seem to be necessary conditions of public art. Dickson disagrees, countering with the claim that the absent work is, like Heidegger's absent step, all the more present by being removed. To my mind this seems prima facie plausible, not least in the sense that, in aesthetic discourse, Tilted Arc is a more 'visible' artwork since its removal than before it. One might also add that there is a kind of physical shadow, or spectre, that hangs over Federal Plaza because of the work's displacement. In this sense, Tilted Arc begins to align with other features of urban experience that flash in and out of the visible range. For example, I have written about the strange spectrality of the Empire State Building which, while certainly present in some obvious way, has the ability to disappear within its own iconicity, its obviousness. ${ }^{2}$ One can credit Andy Warhol's eight-hour and five-minute silent film Empire (1964), which consists of one long shot of the ESB, with this strange aesthetic invisibility. Something similar seems to haunt all iconic structures and works. Sometimes the present is absent, just as sometimes the absent is present.

Sanna Lehtinen's “New Public Monuments: Urban Art and Everyday Aesthetic Experience” builds on existing debates about the goodness/badness of public art to suggest that different examples of public art alter the very definition of the term, never stable in the first place. Examining four quite different works from sites in Helsinki, Lehtinen argues that each transforms the urban surround in varying ways. By isolating the category of "the urban aesthetic," Lehtinen highlights the experiential element of these works, and the way they commemorate or integrate citizens' consciousness with respect to several large concepts, including pleasure and historical memory.

Lehtinen is conscious here of the tendency, already noted, for some works of public art to be driven by motives of commemoration or monumentality. In some ways this may be inevitable: if past and existing public art includes statues and memorials, then new works face the same quandaries of those memorials, especially if they resulted from specific political-cultural commissions. At the same time, some of the most arresting public art, in Helsinki or anywhere, is precisely that which has no specific commemorative function, but instead offers a 'purer' form of aesthetic delight. Lehtinen does not pursue that larger argument here, but one might speculate that one of the kinds of badness to which public art sometimes succumbs is its need to answer historical, cultural, and political imperatives that are conceptually distinct from, and maybe hostile to, strictly aesthetic ones.

Public art creators of my own experience would heartily agree with the last suggestion. They often find themselves at odds with the ideas and demands of constituencies of interest whose expertise and orientation is not especially aesthetic. At the same time, these constituents know what they want, or at least know what they don't want. In this manner of creation, the more fundamental objections to some public art, references above, as ugly or expensive or cumbersome are supplanted by objections that a given design is not appropriate or reverent or sufficiently somber with respect to the origin of the work. Such objections and constraints create whole new vistas of potential badness, since art-by-compromise or art-by-committee is unlikely to be successful art. (There are exceptions: the municipal powers that granted Augustus SaintGaudens license to create public art in honour of Abraham Lincoln, Admiral Farragut, or Robert Gould Shaw were able exactly to match civic interest with artistic genius.)

Andrea Baldini's “The Public-Art Publics: An Analysis of Some Structural Differences Among Public-Art Spheres," though brief, offers a necessary corrective to any blithe or too-hasty notion of what the 'public' in the phrase 'public art' should be taken to mean. Defending a 'multiplicity thesis' (MT), she argues that we must conceive of many heterogeneous publics when it comes to the understanding and assessment of public art. Some public art targets, or invites, specific sub-populations from within the broader public

2 Kingwell, Nearest Thing to Heaven. 
sphere to be, in effect, connoisseurs of the given work. This may or may not be considered elitist. Sometimes the target population is the residential population of a particular neighbourhood, perhaps with a good deal of economic and cultural diversity. Such works can be considered distinct from general or 'total population' works such as the ones that are found in central public squares, municipal spaces, and downtown plazas. Other sub-populations for certain works might relate, again, to commemoration: the target group of the work is a concerned or interested subset of the overall population. Others are not excluded from such works, but the operative notion of public is limited by aesthetic intention.

Thus 'public' here becomes a matter of actual size of target public, as well as the reach of the project - so that, for example, Christo and Jeanne-Claude's Umbrellas, which spanned the Pacific Ocean between California and Japan, is an international work but nevertheless one with a somewhat limited accessibility, especially if one imagined that experiencing the work meant visiting both sites. By contrast, works situated in high-traffic downtown urban environments will have far more exposure, and hence a larger mathematical public, than such expansive yet elusive installations.

Another important vector here is the one defining a spectrum of temporary versus enduring public art. Again The Umbrellas is relevant. Here Baldini would seem to disagree with those who suggest that a dismantled or removed work is still somehow present on the given site. The argument turns, of course, on whether a given work was intended to be temporary or was made temporary by aesthetically extrinsic forces, as in the case of Tilted Arc. One might argue, for example, that it is precisely the controversial removal of Serra's work, and the attendant court case and publicity, which ensure its ongoing presence, whereas a deliberately temporary work, especially perhaps a performative one, should be allowed to go its own way into a fragile temporality. Nuit Blanche events held annually in cities around the world are a vivid example of this: one night only, all night long, but with works of wildly varying quality, and publics of likewise wildly different attitude and composition.

Still by way of contrast, consider enduring works such as Jeanne van Heeswijk's The Blue House (Amsterdam, 2004-09), which create distinct publics, indeed communities that cluster and then expand around the work. This kind of effect, Baldini argues, is example of what Bruno Latour has called "cohabitational time": the time in which we may share with others the experiences of duration and belonging. The basic point here seems unassailable. The public enjoying (or deploring!) a temporary work is quite distinct from the public whose needs are answered by an enduring work, seen and perhaps ignored every day. We could go further and say that such enduring works offer a form of commemoration, and hence allow a public, quite distinct from the standard political or cultural kind. Which is to say, this is transtemporal commemoration of the kind that gives us pleasure and solace by allowing us to revisit a beloved site and the work that sits upon it and transforms it. Such works are more like living totems than they are moribund monuments.

Genre is an aspect of public art that does not receive sufficient attention, argues Elisa Caldarola in "Assessing the Intellectual Value of New-Genre Public Art." Just as there are multiple publics for public art, there are more genre differences than the broad term 'public art' suggests. Indeed, as we delve more deeply, it would seem that the very notion of public art is slippery, multifarious, and unreliable. In particular, Caldarola is interested to follow the lead of Suzanne Lacy, who introduced the term 'New Genre Public Art' (NGPA) to capture forms of extra-mural aesthetic engagement that often depend on immersion, social and political messaging, and sometimes the direct presence of the artist. Such works contrast usefully with more 'standard' works of public art, which are usually objects or installations that stand mutely in place.

In this way, NGPA may be aligned with the tenets of relational aesthetics as explored by Nicholas Bourriaud and Claire Bishop, among others. This theoretical investigation explores the ways in which certain works create miniature and often temporary communities of interest. The experiences in play are understood to be more than 'merely' aesthetic; that is to say, the aim of both artist and work is to foment a form of consciousness, usually political in some sense, among those who view the work. Bourriaud coined the term relational aesthetics to describe the exhibition "Traffic," held at the CAPC musée d'art contemporain de Bordeaux in 1996. Other significant works that exemplify the community-building aspect of such nonstandard work include Rirkrit Tiravanija's gallery installation Pad Thai (Manhattan, New York, 1990; later renamed untitled/Free/Still) where artist and audience together cooked and ate the iconic Thai dish; or 
Thomas Hirschorn's Gramsci Monument (Bronx New York, 2013), Bataille Monument (Kassel, 2002), and Spinoza Monument (Amsterdam, 1999). The latter works involve the creation of temporary and idiosyncratic site-specific celebrations of the philosophers whose influence on Hirschorn has been considerable. They are sprawling participatory museums, part playground and part memorial, all meant to be inviting but temporary. In some cases, the installations are in suburbs well away from city centres and the usual sites of the art world, even of more traditional public art.

Caldarola explores the Bataille Monument at some length, as well as Kathrin Böhm's and Stefan Saffer's Mobile Porch (London, 1999-2003) and assesses their success as good public art based on criteria derived from the notion of socially engaged art (SEA). Both of these works, and others like them, are concerned less with spectacle and beauty than with political effect. Because they are temporary and, of course, in one case mobile - Mobile Porch is just what it sounds like, a roving piece of architecture that offers people the chance to mix and mingle in different locations - these works avoid some familiar tangles about how a piece of public art fits into (or not) its surroundings. At the same time, the works demand a more active response from viewers than the usual request for visual attention sounded by more usual kinds of public art. In a sense, then, these works create their respective public as they go, a kind of dancing alternative to the standand-deliver form of most public art.

With "How Public is Public Art? A Critical Discourse Analysis of the Racial Subtext of Public Monuments at Canada's Pier 21," Patience Adamu, Deon Castello, and Wendy Cukier take a very particular theoretical approach to a vaunted project of commemoration in the city of Halifax, Nova Scotia. The Canadian Museum of Immigration Pier 21 is a large institutional and educational space that offers a detailed and visually impressive account of the immigrant experience of Europeans moving to Canada during the twentieth century. It has some conceptual features in common with the similar institution on Ellis Island in New York. In any event, the authors are concerned less with the museum as such and more with two art pieces that stand outside the Pier 21 building, Hilton Moore's The Volunteers/Les Bénévoles (Halifax, Nova Scotia, 2017) and Armando Barbon's The Emigrant (Halifax, Nova Scotia, 2017).

Both of these bronze pieces have received wide public acclaim, and are often included on 'must-see' lists of tourist experiences in this large Canadian port city, headquarters of Canada's Navy and an important harbour and base since before the American Revolution. The former installation, by Moore, celebrates the contribution of women to the Canadian efforts in service to the Second World War. It depicts three women in various poses of volunteer aid: knitting, serving tea, and collecting scrap metal. The latter work, by Barbon, shows a man with a suitcase hurrying to catch a ship to the 'New World' as his family stands sadly behind, watching him go. A plaque fronting this latter sculpture carries the inscription (in England, French, and Italian) "The pain of separation he overcame, with faith and hope his heart aflame..."

The public approval of these works, the authors argue, together with the sentimentalized and politically charged messages they convey, hide a deeper story of "Canada's enduring commitment to white supremacy, Eurocentricity and colonization, when viewed through the eyes of racialized immigrants." Using critical discourse theory to explore and query the subtextual messages of the works, the authors find an unfortunately typical story of self-congratulation, assumed whiteness, and social exclusion. Thus, they suggest, a physically inclusionary work may become, despite intentions, a socially exclusionary work when set against a larger backdrop of colonial domination. Even when diverse are included in The Volunteers - the knitting woman is perhaps Mi'kmaw, the tea-server Black, the scrap-gatherer young - or when The Emigrant signals the multicultural origins of post-war Canada because the man is (maybe) Italian, there are persistent visual cues concerning difference, separateness, and lack of voice. Intention becomes exclusion, adding a dimension of (let us call it) political badness that must inform any consideration that public space, and so $a$ fortiori public art, as non-rival and non-excludable. In short, one can be excluded even when one is freely able to view a given public work. The same might be argued about public space more generally: not all gates are physical ones.

In “The Artists Village: Openly Intervening in the Public Spaces of the City of Singapore,” Adrian Tan explores notions of public and political by focusing on the work of the Singaporean collective known as The Artists Village in works ranging from the 1980s to 2015. Invoking Umberto Eco's landmark book The Open Work (1962), Tan makes a compelling case that these artists, intervening in shopping malls, public 
transit sites, and national monuments, have made an ongoing argument for openness and liberation in the notoriously controlling nation-state. Here, public littering, gum-chewing, and unflushed toilets carry hefty fines, as do otherwise private activities such as walking naked in your own abode. Under these conditions of repressive state intervention, The Artists Village have made a series of witty and sometimes angry - also, let it be said risky - works that push back on state control.

More than this, though, as Tan argues, the echo of Eco is heard in their ideas of art as open and resonant. His notion of "perceptive ambiguities" reverberates throughout the works discussed. We note that Eco is talking in this essay of all artwork, and using a background from Heidegger's "Origin" essay and Croce's aesthetic theory to expand and extend reflection on the work that art does, but in the sense that he sees art as opening a space for ontological reflection, the specifically public works of The Artists Village make a case for what we might consider a doubled openness. That is, there is the opening any work of art might perform, or allow, the multiplicities that cannot (and should not) be controlled by the artist; and then there is the peculiar/particular kind of openness afforded only by works that stand in 'open' spaces such as public sites. This is good an idea of the lasting impact of public art as we are likely to see. And it usefully reverses the polarity of the original provocative call of this special issue. Does public art have to be bad art? No, on the contrary: public art is, at least in terms of demanding and creating openness, always on the way to being good art. This does not obviate aesthetic judgment, of course, nor does it belay the creation of bad public art, any more than a general poetics of the open work prevents the production of bad art of all kinds. But there is something special about the affordances of public art when it comes to Eco's powerful idea that a work is never completed, only complicated by its publics and chance alike.

Finally, Bart Wissink and Lara van Meeteren, in "Public Art in the Private City: Control, Complicity and Criticality in Hong Kong," make a theoretical contribution that, at the time of this writing, is more pertinent than ever. The Summer 2019 pro-democracy protests in Hong Kong highlighted a long history of political and economic control exerted by the government in Beijing, a history which gained momentum following the 1997 handover from British administration and was hastened by planned Chinese celebrations of the former colony's founding and the looming revocation of the partial freedoms granted by Beijing under a transition agreement. By the fall of 2019 the protests had grown more violent and Beijing's responses more bellicose. Clashes between protesters and police mounted in intensity, with some deaths as well as dozens of injuries, all shadowed by the presence of a battalion of Chinese People's Army troops barracked in central Hong Kong.

The authors focus their attention on issues that extend beyond the context of contemporary Hong Kong. By addressing "control, complicity, and criticality" in public art, they aim to expose subtle - and not so subtle - curbs on the potential critical function of public art. Sometimes this is a matter of corporate or municipal funding, such that responding artists are (as mentioned earlier) put in an uncomfortable position of compromise with respect to the wishes of the committees or boards who have commissioned a given work. Sometimes this leads in turn to forms of complicity on the part of both commissioning bodies and artists, such that instead of a win-win the situation becomes one of win-lose or, worse, lose-lose. Criticality is the first casualty of compromise.

The authors focus these general considerations by detailing two Hong Kong works, Antony Gormley's Event Horizon (2015) and Our 60-second friendship begins now (2016) by Sampson Wong Yu-hin and Jason Lam Chi-fai. They note the widely held view that public art in Hong Kong is too often boring, bland, and merely decorative, even as wealthy developers and other corporate interests invest heavily in 'name-brand' artists and institutions elsewhere. The works chosen for close consideration seem to expand the boundaries of this generalized blandness. Gormley's project involved the installation of twenty-seven human figures on rooftops across the Central and Admiralty districts of Hong Kong. These figures, angelic or demonic or both, disrupted the otherwise machine-like density of central Hong Kong's skyline. There was opposition, and when Gormley spoke about the project to a large university audience, he made his intentions clear: "It's not art's job to be acceptable," he said. "In fact, its job is to question everything. The last thing that art has to do is please people. I think it should disturb, undermine, and question." This familiar general view was made more particular in a later newspaper interview, in which Gormley said, "This art is about Hong Kong's growing awareness of its own unique identity that is neither its colonial past or [derived from] its new masters in Beijing." 
That sentiment was, in 2015, rather optimistic. Its origins in the Occupy Central movement, based on New York's Occupy Wall Street protest, were clear; and those same sentiments are drivers of the current anti-Beijing protests. But whether public art helps much in these political efforts is debatable. If we were to include graffiti as a species of activist public art, spontaneous and sometimes angry as I experienced myself when I visited Hong Kong in August 2019, this would be a more direct representation of the frustration of young Hong Kongers in the face of the "new masters in Beijing." Wong and Lam's work, which extends a project of activist art rooted in the Umbrella Movement and Occupy Central, is perhaps a better example of public art that might raise consciousness and even foment resistance. But their project, a text and image work that played along the external surface of the ICC Building in Kowloon, the tallest in Hong Kong, was not cramped by its corporate origins. By subverting expectations and not "following the rules," the two introduced key critical elements into what might have been a hackneyed or compromised work. Accompanying press releases supplemented the installation, timed to coincide with the arrival of highranking Beijing functionaries, whose presence is always fawned over in formal settings. This social ordering tells you all you need to know about who holds the reins of real power in Hong Kong society.

Wong and Lam remained undaunted, even in the face of cynical criticism that they were being 'unprofessional' in their sly resistance. This charge, sounded everywhere public art is to be found, is the last refuge of private capital and status quo power. It is a sad but fitting note on which to end, and almost Trumpian attempt at reversal of values, such that criticism is always pre-ordained as unacceptable. Let us hope that courageous public artist will recognize it for the toxic nonsense it is, and keep creating works that disturb, undermine, and question.

\section{References}

Eco, Umberto. The Open Work. Harvard University Press 1989.

Kingwell, Mark. Nearest Thing to Heaven. Yale University Press, 2006.

Walton, Kendall. “Categories of Art”. Philosophical Review, 79(3) (1970): 334-367. 